\title{
Importance of GLUT1 in differential diagnosis of vascular anomalies
}

\section{Importância da GLUT1 no diagnóstico diferencial das anomalias vasculares}

\author{
Tiago João da Silva Filho', Denise Hélen Imaculada Pereira de Oliveira', Ilnara de Souza Moura', \\ Layssa Karolinne da Silva Medeiros', Amanda Katarinny Goes Gonzaga', \\ Veruska Lima Moura Brasil², Lélia Maria Guedes Queiroz'
}

\begin{abstract}
Vascular anomalies (VAs) include a group of distinct lesions, such as vascular system congenital malformations, as well as benign and malignant vascular tumors. These lesions may present similar clinical and histopathological features, leading to mistaken diagnoses and incorrect treatment choices. It is important that professionals responsible for monitoring the development of VAs conduct precise investigations and use the appropriate terminology. The human glucose transporter protein isoform 1 (GLUT1) has been proposed as a tool to aid in differential diagnosis between different VAs, given that it is a sensitive and specific marker for identification of infantile hemangiomas (HIs) in any organ. This article presents a review of the literature on this protein as an effective tool for identification and possible differential diagnosis between several VAs.
\end{abstract}

Keywords: vascular malformations; hemangioma; diagnosis differential.

\section{Resumo}

As anomalias vasculares (AVs) incluem um grupo de lesões distintas, como as más formações congênitas e os tumores vasculares benignos ou malignos. Estas lesões podem apresentar características clínicas e histopatológicas semelhantes, ocasionando equívocos diagnósticos e terapêuticos. Uma investigação precisa e o uso de terminologia adequada são fundamentais para as decisões do profissional responsável pelo acompanhamento da evolução de uma AV. A isoforma 1 da proteína humana transportadora de glicose (GLUT1) tem sido proposta como uma ferramenta auxiliar para o estabelecimento de diagnóstico diferencial entre AVs, uma vez que representa um marcador sensível e específico para a identificação de hemangiomas da infância de qualquer órgão. Este estudo objetiva fazer uma revisão da literatura acerca desta proteína como ferramenta eficaz na identificação e no possível diagnóstico diferencial entre as diversas AVs.

Palavras-chave: más formações vasculares; hemangioma; diagnóstico diferencial. 


\section{INTRODUCTION}

Vascular anomalies (VAs) are lesions of a congenital or acquired nature, which predominantly involve vascular structures. This group of conditions includes all congenital malformations of the vascular system (VMs) and both benign and malignant vascular tumors. ${ }^{1-4}$

Infantile hemangiomas or hemangiomas of infancy (HIs) are the most common vascular anomaly of childhood and exhibit formation of blood vessels with incomplete architecture, surrounded by hyperplasic endothelial cells. They may or may not be present at birth and follow a characteristic pattern of proliferation which is often followed by spontaneous involution. ${ }^{1,5-7}$

Precise workup and use of the correct terminology are important elements in the decision-making process of the professional responsible for managing VAs. In many cases, detailed patient history and clinical examination are sufficient to define diagnosis, but other methods should be considered in cases in which clinical data leave room for doubt or a possible different diagnosis would affect treatment.

The human glucose transporter protein (GLUT1), identified by North et al., ${ }^{8}$ has proven useful as a supplementary tool for assessment of the prognosis of certain types of tumor and for differential diagnosis between VAs, because it is a sensitive and specific marker that can be used to identify HIs in any organ.

The objective of this study is to review the literature to compile information on HIs and GLUT1 and discuss whether this protein can actually be considered an effective tool for the identification of these lesions.

\section{REVIEW OF THE LITERATURE}

\section{Vascular anomalies}

For a long time, there was no consensus on VA terminology or classification, with a negative impact on treatment indications, which were very often applied in a heterogeneous and non-parametrized manner, increasing the likelihood of iatrogeny. ${ }^{9}$ The first classifications adopted to categorize these conditions were of a purely descriptive nature. These were successively replaced by classifications based on anatomopathological and embryological findings, and by characteristics based on their biological behavior., ${ }^{2,4}$

Virchow ${ }^{10}$ was the first to classify vascular anomalies, using their microscopic appearance as the basis for classifying them as simplex, cavernosum and racemosum angiomas. His classification was based on the belief that each of these types could change into the others through cell proliferation or dilation of vessels.

For years, the term "hemangioma" was widely and indiscriminately employed to designate VAs which are completely distinct in terms of genesis, clinical and histopathological characteristics, clinical course and prognosis. ${ }^{11}$ In response to this, the terms "capillary hemangioma" or "strawberry hemangioma" were used to designate what is nowadays known as the superficial form of HI, which is a true tumor, generally with no major clinical significance or consequences and, in most cases, with merely cosmetic effects. . $^{6,7,11}$

At the same time, the term "flat hemangioma" was the name given to what is today classified as a port-wine stain, which is a VM that is present at birth in almost all cases, grows in proportion to the child's development, is of a permanent nature and may be associated with a large number of different syndromes, such as Bean syndrome and Mafucci syndrome. Additionally, adjectives such as "cavernous" (which is a descriptive term from histology and should be reserved for that use) referred to clinical characteristics, such as the bluish color suggestive of deep lesions. ${ }^{7,9}$ Thus, lesions of different types, such as the deep form of HI, which regresses spontaneously, and permanent subcutaneous VMs, which only have the bluish color in common, were both classified as cavernous.

In 1982, Mulliken and Glowacki ${ }^{1}$ proposed a new classification of vascular lesions based on clinical signs, histopathological findings and natural history, distinguishing between "hemangiomas" and "vascular malformations".

The absence of an internationally-accepted diagnostic classification prevented standardization of the appropriate treatment, throwing up barriers to construction of management protocols and compromising comparisons between different treatment options. ${ }^{9}$ In view of this, Mulliken and Glowacki's classification was revised in 1996, leading to the creation of a new classification that was adopted as the official position of the International Society for the Study of Vascular Anomalies (ISSVA), in which vascular lesions are classified into one of two groups: tumors and vascular malformations. ${ }^{2}$

Currently, the internationally-accepted classification is based on biological features. More specifically, it is based on the correlation between biological cellular behavior and clinical course, with a impact on the type of treatment that will be prescribed. ${ }^{9}$ However, the use of outdated nomenclatures persists, leading to incorrect diagnoses and, consequently, incorrect treatments. ${ }^{12,13}$ 
Hassenein et al. ${ }^{12}$ searched the PubMed database for all publications that contained the term "hemangioma" in the title or abstract in 2009, excluding veterinary studies. They found that the term "hemangioma" was used incorrectly, according to the ISSVA classification, in $71.3 \%$ of these publications. Patients whose lesions were incorrectly classified were more likely to be given the wrong treatment $(20.6 \%)$, whereas patients whose lesions were classified according to the ISSVA system were subjected to $0.0 \%$ erroneous management during treatment. Additionally, the mean age of patients in studies that used the classification was lower (4.1 months) than in the studies that did not use it (36.1 years).

As is true of any classification, the ISSVA system is not absolute. However, its simplicity and clinical relevance have enabled important steps to be taken towards improved management of vascular anomalies.

\section{Infantile hemangioma or hemangioma of infancy}

HIs are the most common type of vascular tumor, affecting around $10 \%$ of all infants up to 1 year old. ${ }^{6,14}$ They are more frequent in premature, Caucasian, female and low birth weight babies, affecting up to $30 \%$ of neonates weighing less than $1,000 \mathrm{~g} .{ }^{15}$ Maternal risk factors include advanced age, preeclampsia and placental abnormalities. ${ }^{16}$

They typically have onset from 2 weeks to 2 months after birth, may be single or multiple, involve one or several systems, and can be focal or regional. ${ }^{17}$ Approximately $80 \%$ of patients have single lesions and four or more lesions in the same patient is rare. The skin is the most often involved organ and the head and neck $(60 \%)$, and trunk $(25 \%)$ are the most affected areas. Size can range from a few millimeters to several centimeters. ${ }^{18,19}$

Despite the elevated incidence of HIs, their etiology remains unclear. However, North et al. ${ }^{20}$ suggested that the origin was possibly placental after studying similarities between the blood vessels in HIs and in the placenta. They employed vascular markers that exhibit immunopositivity in the placenta, including GLUT1, Lewis Y, merosin and Fc $\gamma$ receptor II (receptor for G-2 immunoglobulin). They then tested different types of VA, including 66 cases of "hemangiomas", in addition to malignant tumors of a non-vascular origin and placenta samples. They observed coexpression of all four markers in HIs and placenta, but did not observe expression in the other lesions which, according to the authors, implies that there is an intimate relationship between the two, suggesting a link with the origin of these tumors. ${ }^{20}$

Clinically, the natural history of HI can be divided into three phases: the first is the growth or proliferative phase, followed by spontaneous regression or the involutive phase, and then a third phase of final equilibrium or the involuted phase. . $^{1,5,13,21}$

During proliferation, the tumor presents as a solid lesion that is compressible, exhibits increased temperature, and is well defined with signs of increased blood flow. In some cases, increased peritumoral vascularization may be observed, which explains the increased volume on effort and when crying. ${ }^{22,23}$ Histologically, clusters of proliferative endothelial cells form solid cords and masses, sometimes with formation of small vascular lumens (Figure 1). These cells tend to group together, forming lobes separated by fine bundles of connective tissue. None of the lobes are encapsulated or fibrotic and many contain normal tissue and have a feeder artery. Additional findings can include thrombosis and hemosiderin deposits, which are limited to areas of acute inflammation or ulceration. Pericytes, fibroblasts and, particularly, mast cells are numerous in the later stage of proliferation.

In this phase, the tumor grows rapidly and can attain dimensions that are considerable in proportion to the size of the child. Depending on location, there may be functional, esthetic and psychological compromise. Neoplastic growth can cause necrosis of the lesion due to vascular insufficiency, primarily in the central portion, causing recurrent ulceration, bleeding and localized infectious processes, although these factors do not exhibit any relationship with the lesion's prospects for regression. The proliferative phase is most pronounced during the first 3 to 6 months of life and, in the majority of cases, the tumor will reach its maximum dimensions between nine and 12 months, although this can extend into the second year of life. ${ }^{5,23}$

The involution phase is characterized by differentiation of mesenchymal cells into adipocytes and the

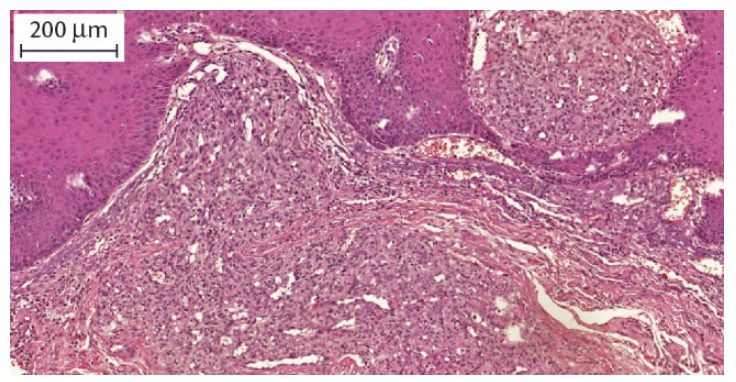

Figure 1. Photomicrograph demonstrating the histopathological characteristics (H/E) of HI - Panoramic Viewer 1.15.2 (3DHISTECH Kft. 29-33, Konkoly-Thege M. str. Budapest, Hungary, H-1121). 
endothelial cells surrounding the small vascular lumens undergo apoptosis, resulting in color changes (from bright red to pale or grey) and consequent resolution of the lesion. ${ }^{24}$ It has been estimated that the pace of involution is at $10 \%$ per year and that $70 \%$ will already be involuted by 7 years of age. Once this phase has stabilized, the hemangioma is defined as involuted. ${ }^{23}$ However, reaching this phase does not necessarily imply return to normality, since sequelae may remain at the site of the lesion, including tumor remnants, cutaneous atrophy, areas of scarring, telangiectasias, hypochromic or hyperchromic skin, alopecia and irregular borders..$^{13}$

Although HIs are classically diagnosed on the basis of patient history, physical examination and predictable clinical course, these are the only vascular lesions that exhibit positive marking for GLUT1 when biopsy specimens are analyzed and they also exhibit greater endothelial cell volumes. ${ }^{25}$ It has been estimated that just 10 to $20 \%$ of HIs truly require treatment. ${ }^{13}$ In the majority of cases no intervention whatsoever is needed and lesions regress spontaneously. The skin or mucosa covering the lesion may exhibit mild atrophy, pallor and, finally, resolution of the vascular telangiectasia. ${ }^{5}$

However, in some cases, the natural history of HIs leads to complications that make it impossible to restrict management to monitoring without interventions. Ulceration is the most common complication during the proliferative phase. Anatomic site is important and many complications are related to this factor, such as an expanding tumor causing compression of important structures, such as in the parotid region, involvement of the airways, and tumors located in the orbital area and the eyelids. ${ }^{5}$ Choice of treatment should take into account patient age, size, number and location of lesions, stage of progression, and presence of other associated symptoms. ${ }^{22}$

Hemangiomas can also present as congenital lesions that, in contrast with HI, are completely formed at birth. Congenital hemangiomas are classified as rapidly involuting congenital hemangiomas or as non-involuting congenital hemangiomas. ${ }^{21}$

These entities were considered variants of $\mathrm{HI}$ for a long time, but a number of studies have demonstrated histopathological and immunophenotypical differences between the two groups, indicating that it is unlikely that they are part of a single spectrum of lesions. ${ }^{8,21}$ North et al. ${ }^{26}$ demonstrated positive GLUT1 expression in HI, whereas congenital hemangiomas do not exhibit this positivity, thereby classifying them as distinct lesions.

\section{Isoform 1 of the human glucose transport protein (GLUT1)}

Glucose is both the primary source of energy and an important substrate for synthesis of proteins and lipids in the cells of mammals. It provides energy in the form of ATP through glycolysis and the citric acid cycle (Krebs cycle), and in the form of NADPH via the pentose phosphate pathway. It is also utilized in synthesis of glycerol and for triglyceride production and provides intermediates for synthesis of nonessential amino acids. ${ }^{27}$

Since blood glucose levels in mammals are maintained within a narrow range by a number of homeostasis mechanisms, the majority of cells receive glucose from the interstitial fluid through a process of passive transport known as facilitated diffusion, pushed through the plasmatic membrane by the concentration gradient into the cell interior. ${ }^{28}$ Only the epithelial cells of the small intestine brush border and the proximal tubules of the kidneys absorb or reabsorb glucose against its electrochemical gradient through a secondary mechanism of active transport, the sodium-potassium pump. ${ }^{27}$

Glucose transport processes are mediated by two distinct families of glucose transporters that are related structurally. The facilitated passive transport system is mediated by the facilitated glucose transporter family of proteins (GLUTs), while active transport is mediated by the sodium-dependent glucose cotransporter family of proteins (SGLTs). ${ }^{29-31}$

The GLUT proteins have molecular weights from 50 to $60 \mathrm{kDa}$ and are labeled GLUT1 to 12 , HMIT-H+ - binds to myo-inositol - and GLUT14, according to the chronological order of their identification and description. ${ }^{31-33}$ Human GLUT1 has 492 amino acids and a molecular weight of approximately $54 \mathrm{kDa} .{ }^{27}$

An in-depth review of the genome on GenBank indicated that GLUTs 1 through 12 and HMIT may represent all of the members of the facilitated glucose transport proteins in humans. ${ }^{29}$ Analysis of these proteins indicates that this transporter family has a tertiary structure of 12 hydrophobic transmembrane domains. These domains are connected by intracellular and extracellular hydrophilic segments and have $\mathrm{NH}_{2}$ and $\mathrm{COOH}$ cytoplasmic terminals (Figure 2). ${ }^{31,34,35}$ Studies comparing sequences of all members of the family have shown that the sequences are most conserved in the transmembrane regions, suggesting that it is these domains that are responsible for the characteristic that is common to all of the GLUTs, which is the capacity to transport glucose..$^{27,36}$ These 


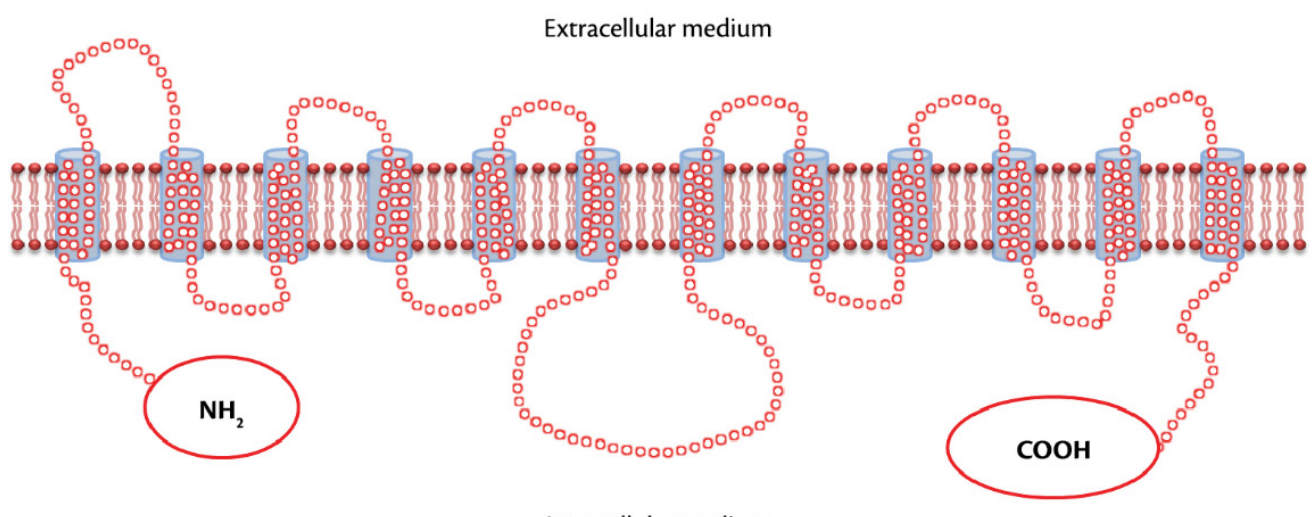

Intracellular medium

Figure 2. Two-dimensional molecular structure of GLUT.

data suggest that the conserved amino acids play important roles in bonding to the substrate and/or in changing conformations during the transport process. Additionally, the presence of areas in common suggests this may have an origin in a shared ancestral gene. ${ }^{27}$

The most divergent regions are loops 1 and 9, and the two terminal regions, suggesting that these domains may be responsible for specific characteristics of each isoform, such as cell location, kinetic profile, hormone regulation and immunogenicity. ${ }^{27,36}$

\section{GLUT1 in differential diagnosis of VAs}

GLUT1 is highly expressed in the microvascular endothelium of barrier tissues in which selective glucose flow from the blood to tissues is extremely important, such as in the central nervous system, retina, iris, ciliary muscle, endoneurium - a delicate web of loose connective tissues that surround each nerve fiber in peripheral nerves - and in the placenta, ${ }^{8,37-39}$ and may play a vital role in the entry of glucose into these strongly protected tissues. ${ }^{37}$ Expression is also observed in erythrocytes, accounting for around $5 \%$ of the membrane proteins in this cell type, in germinal centers of lymphoid tissues and renal tubules, and in adipose tissue and certain hepatic cells..$^{27,37-39}$

The protein is not expressed in the vasculature of any other normal tissue or in other vascular tumors. It has no relationship with mitotic activity and is considered a sensitive and specific marker for diagnosis of HI, since it is present during all phases of progression ${ }^{2,4}$ (Figure 3).

North et al. ${ }^{8}$ studied immunohistochemical markers of GLUT1 in a number of vascular anomalies. They observed intense immunoreactivity for GLUT1 in HIs, demonstrating greater than 50\% marking in endothelial cells from lesion microvessels in $97 \%$ of cases. Additionally, no immunoreactivity for GLUT1

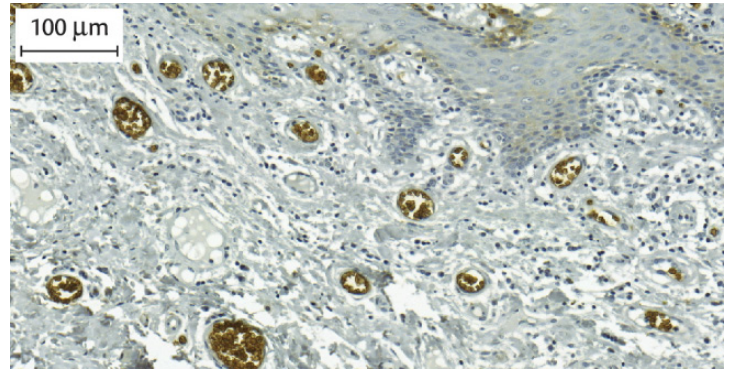

Figure 3. Photomicrograph showing immunoexpression of GLUT-1 in HI - Panoramic Viewer 1.15.2 (3DHISTECH ${ }^{\odot}$ Kft. 29-33, Konkoly-Thege M. str. Budapest, Hungary, H-1121).

was observed in any other type of VA. These findings established GLUT1 as a highly sensitive and specific marker for identification of HIs in any organ.

Mo et al. ${ }^{40}$ concluded that there was a need for appropriate terminology to describe hepatic vascular anomalies, which prompted them to conduct a study of 19 cases using several different vascular markers, including GLUT1. Their results indicate that there are two distinct groups of hepatic vascular lesions in neonates and children: hepatic HI, which is positive for GLUT1, and the hepatic VMs, which are GLUT1 negative. The authors therefore concluded that GLUT1 is an effective tool for differentiating between hepatic HIs and VMs.

Johann et al., ${ }^{41}$ tested for GLUT1 immunoexpression in oral "hemangiomas", oral VMs and oral pyogenic granulomas (PG) in order to investigate the accuracy of histological diagnosis of these anomalies. They observed that none of the cases of oral benign vascular lesions exhibited immunopositivity for GLUT1. Cases initially diagnosed as oral hemangiomas also proved to be negative for GLUT1 and were therefore reclassified after more detailed analysis of the cases. Additionally, 
all cases initially classified as GPs and VMs were immunonegative for the protein, demonstrating the effectiveness of histological analysis for these lesions.

Osaki et al ${ }^{42}$ conducted a study of orbital vascular anomalies. They analyzed ten cases of HI and ten cases of orbital encapsulated cavernous venous lesions or orbital VMs. They found that all cases of HI were positive for GLUT1, whereas none of the VM cases were positive. According to the authors, the immunopositivity for GLUT1, observed only in the HIs, highlights an essential difference and as a marker makes the greatest contribution to improving diagnostic precision during later stages, when the solid areas of HIs undergo transformation into ectasic vascular channels, but remain GLUT1 positive.

Oliveira et al. ${ }^{43}$ analyzed immunohistochemical expression of 30 cases initially diagnosed as "hemangiomas" and 30 cases diagnosed as oral PG. The immunohistochemical test showed that only seven of the "hemangioma" cases were true HIs. Specimens that were GLUT1 negative were reclassified as oral PG (ten) or VM (13). None of the PG cases were positive for GLUT1 and so their initial histological diagnoses were maintained. In view of these findings, the authors concluded that histopathological characteristics are not alone enough to guarantee correct diagnosis of oral HIs.

\section{DISCUSSION}

VAs are disorders of vasculogenesis, angiogenesis or lymphangiogenesis, and are among the most common pediatric abnormalities. ${ }^{44}$ HIs have the greatest relative frequency of the VAs. ${ }^{1,21}$ Despite their elevated frequency, there is still a need to adopt a standardized terminology common to both clinicians and pathologists. Currently, the same term can be used for different entities while, on the flip side, the same lesion can be assigned to different categories by different health professionals. The term "hemangioma" has often been used to denote a wide range of VAs. ${ }^{7,12,18}$ This terminological confusion can contribute both to incoherence that affects clinical management of patients and to introduction of biases into studies of the subject. ${ }^{12,45}$

Although almost 20 years have passed since the ISSVA classification was established, nomenclature errors are still a common occurrence. ${ }^{12}$ Correct identification of the type of vascular anomaly is not only essential because of their different clinical, radiographic and pathological characteristics and their morbidity, but also because different types require different treatments. ${ }^{9}$
Application of the term "hemangioma" for a varied range of VAs is not the only problem related to naming these lesions. A variety of subclassifications and neologisms that are not parametrized can still be observed in current work, making it difficult to standardize terminology and, as a consequence, diagnosis and treatment.

Correct treatment starts with correct diagnosis, since a significant number of patients with vascular lesions receive ineffective and potentially harmful treatment because of erroneous diagnoses. ${ }^{46}$

Many patients do receive the correct treatment even when the lesion is misdiagnosed. Nevertheless, incorrect designations are associated with a great risk of the patient receiving inappropriate treatment. ${ }^{12}$

It can be difficult to achieve differential diagnosis between different VAs on the basis of histology, particularly between HIs, GPs and VMs, because HI in the proliferative phase and with inflammation appears very similar to $\mathrm{PG}$, while histological similarities to VMs can be observed in the involution phase. As such, it is very important to compile well-described clinical information and patient history. Additionally, when necessary, biomarkers should be used to aid in differential diagnosis and lesions should be reclassified as appropriate. ${ }^{8,41,47-51}$

According to Younes et al., ${ }^{38}$ the observation that lesions continue to exhibit GLUT1 immunoexpression in the proliferative phase could be explained by the increase in proliferative activity and in energy requirements, because the protein is capable of transporting glucose and also other molecules. However, the fact that this protein remains in the cells of these lesions during the involuted phase implies that its expression is not related to a temporary adaptation caused by a need for glucose to support a high rate of proliferation, and one result is the marker's specificity for identification of HIs. ${ }^{8}$

When VAs previously thought to be HIs exhibit negative immunomarcation for GLUT1, the solution is to reclassify them as other entities, on the basis of clinical and histopathological characteristics described in the literature. . $, 8,20,25,26,52$ This is extremely important, primarily with relation to prescribing treatment, since HIs generally exhibit spontaneous involution, which cannot be expected in cases of GPs and VMs. ${ }^{12,41}$

Many studies that analyzed GLUT1 expression in samples diagnosed as HIs on the basis of histopathology ${ }^{20,26,40,42,53-57}$ demonstrated that all of the cases analyzed were immunopositive for the protein, providing support for the hypothesis advanced by North et al., ${ }^{8}$ when GLUT1 was confirmed as a sensitive and specific marker for identification of HIs. 
On the other hand, several studies s $^{41,43,58-60}$ demonstrated that not all specimens diagnosed by histopathology as "hemangiomas" present immunopositivity for the GLUT1 protein and all of these studies considered that only those samples that were GLUT1 positive came from true HIs, showing that over the years this marker has been widely used for the purposes of diagnosis, in addition to confirming its efficacy and reliability as a diagnostic marker.

\section{CONCLUSIONS}

Patients with VAs continue to be misdiagnosed because of the complexity involved in differentiating these lesions. Many studies are still being conducted without correct parametrization, introducing biases that can compromise the results and return incorrect information. It is therefore important that centers where teaching, research or diagnosis take place should adopt the ISSVA classification when defining new cases, using tools such as GLUT1. Additionally, older cases should be revisited and, if necessary, reclassified, in order to achieve better communication between professionals and to ensure that research is more trustworthy and better parametrized.

\section{REFERENCES}

1. Mulliken JB, Glowacki J. Hemangiomas and vascular malformations in infants and children: a classification based on endothelial characteristics. Plast Reconstr Surg. 1982;69(3):412-22.http:// dx.doi.org/10.1097/00006534-198203000-00002. PMid:7063565.

2. Enjolras $\mathrm{O}$, Mulliken JB. Vascular tumors and vascular malformations (new issues). Adv Dermatol. 1997;13:375-423. PMid:9551150.

3. Metry DW, Hebert AA. Benign cutaneous vascular tumors of infancy: when to worry, what to do. Arch Dermatol. 2000;136(7):905-14. http://dx.doi.org/10.1001/archderm.136.7.905. PMid:10890993.

4. Enjolras O, Wassef $M$, Chapot R. Introduction: ISSVA classification. New York: Cambridge University Press; 1997. [citado 2014 abr 23]. http://assets.cambridge.org/97805218/48510/excerpt/9780521848510_ excerpt.pdf.

5. Tucci FM, De Vincentiis GC, Sitzia E, Giuzio L, Trozzi M, Bottero $\mathrm{S}$. Head and neck vascular anomalies in children. Int J Pediatr Otorhinolaryngol. 2009;73(Supl 1):S71-6.http://dx.doi.org/10.1016/ S0165-5876(09)70014-X. PMid:20114160.

6. Drolet BA, Esterly NB, Frieden IJ. Hemangiomas in children. N Engl J Med. 1999;341(3):173-81.http://dx.doi.org/10.1056/ NEJM199907153410307. PMid:10403856.

7. Mulliken JB, Fishman SJ, Burrows PE. Vascular anomalies. Curr Probl Surg. 2000;37(8):517-84.http://dx.doi.org/10.1016/S00113840(00)80013-1. PMid:10955029.

8. North PE, Waner M, Mizeracki A, Mihm MC Jr. GLUT1: a newly discovered immunohistochemical marker for juvenile hemangiomas. Hum Pathol. 2000;31(1):11-22.http://dx.doi.org/10.1016/S00468177(00)80192-6. PMid:10665907.

9. Hiraki PY, Goldenberg DC. Diagnosis and treatment of infantile hemangioma. Rev. Bras. Cir. Plást. 2010;25(2):388-97.
10. Mulliken JB, Fishman SJ, Burrows PE. Vascular anomalies. Curr Probl Surg. 2000;37(8):518-84.

11. Gontijo B, Silva CMR, Pereira LB. Hemangiomaofinfancy. An Bras Dermatol. 2003;78:651-73.

12. Hassanein AH, Mulliken JB, Fishman SJ, Greene AK. Evaluation of terminology for vascular anomalies in current literature. Plast Reconstr Surg. 2011;127(1):347-51.http://dx.doi.org/10.1097/ PRS.0b013e3181f95b83. PMid:21200229.

13. Lowe LH, Marchant TC, Rivard DC, Scherbel AJ. Vascular malformations: classification and terminology the radiologist needs to know. Semin Roentgenol. 2012;47(2):106-17.http:// dx.doi.org/10.1053/j.ro.2011.11.002. PMid:22370189.

14. Spiteri Cornish K, Reddy AR. The use of propranolol in the management of periocular capillary haemangioma--a systematic review. Eye (Lond). 2011;25(10):1277-83..http://dx.doi.org/10.1038/ eye.2011.164. PMid:21738233.

15. Gampper TJ, Morgan RF. Vascular anomalies: hemangiomas. Plast Reconstr Surg. 2002;110(2):572-85, quiz 585, discussion 587-8.http:// dx.doi.org/10.1097/00006534-200208000-00032. PMid:12142679.

16. Frieden IJ, Haggstrom AN, Drolet BA, et al. Infantile hemangiomas: current knowledge, future directions. Proceedings of a research workshop on infantile hemangiomas, april 7-9, 2005, Bethesda, Maryland, USA. Pediatr Dermato. 2005;22(5):383-406.

17. Chiller KG, Passaro D, Frieden IJ. Hemangiomas of infancy: clinical characteristics, morphologic subtypes, and their relationship to race, ethnicity, and sex. Arch Dermatol. 2002;138(12):1567-76. http://dx.doi.org/10.1001/archderm.138.12.1567. PMid:12472344.

18. Werner JA, Dünne AA, Folz BJ, et al. Current concepts in the classification, diagnosis and treatment of hemangiomas and vascular malformations of the head and neck. Eur Arch Otorhinolaryngol. 2001;258(3):141-9.http://dx.doi.org/10.1007/s004050100318. PMid:11374256.

19. Fevurly, RD, Fishman, SJ. Vascular anomalies in pediatrics. Surg Clin North Am. 2012;92(3):769-800.

20. North PE, Waner M, Mizeracki A, et al. A unique microvascular phenotype shared by juvenile hemangiomas and human placenta. Arch Dermatol. 2001;137(5):559-70. PMid:11346333.

21. Ballah D, Cahill AM, Fontalvo L, et al. Vascular anomalies: what they are, how to diagnose them, and how to treat them. Curr Probl Diagn Radiol. 2011;40(6):233-47. PMid:21939817.

22. Frieden IJ, Eichenfield LF, Esterly NB, Geronemus R, Mallory SB, The Guidelines/Outcomes Committee. Guidelines of care for hemangiomas of infancy. J Am Acad Dermatol. 1997;37(4):631-7. http://dx.doi.org/10.1016/S0190-9622(97)70183-X. PMid:9344205.

23. Boye $E$, Jinnin $M$, Olsen BR. Infantile hemangioma: challenges, new insights, and therapeutic promise. J Craniofac Surg. 2009;20(Supl 1):678-84.http://dx.doi.org/10.1097/SCS.0b013e318193d6c1. PMid:19190505.

24. Yu Y, Fuhr J, Boye E, et al. Mesenchymal stem cells and adipogenesis in hemangioma involution. Stem Cells. 2006;24(6):1605-12.http:// dx.doi.org/10.1634/stemcells.2005-0298. PMid:16456130.

25. Mulliken JB, Enjolras O. Congenital hemangiomas and infantile hemangioma: missing links. J Am Acad Dermatol. 2004;50(6):87582.http://dx.doi.org/10.1016/j.jaad.2003.10.670. PMid:15153887.

26. North PE, Waner M, James CA, Mizeracki A, Frieden IJ, Mihm $M C$ Jr. Congenital nonprogressive hemangioma: a distinct clinicopathologic entity unlike infantile hemangioma. Arch Dermatol. 2001;137(12):1607-20.http://dx.doi.org/10.1001/ archderm.137.12.1607. PMid:11735711. 
27. Zhao FQ, Keating AF. Functional properties and genomics of glucose transporters. Curr Genomics. 2007;8(2):113-28.http:// dx.doi.org/10.2174/138920207780368187. PMid:18660845.

28. Widdas WF. Old and new concepts of the membrane transport for glucose in cells. Biochim Biophys Acta. 1988;947(3):385-404. http://dx.doi.org/10.1016/0304-4157(88)90001-9. PMid:3048400.

29. Joost HG, Bell GI, Best JD, et al. Nomenclature of the GLUT/ SLC2A family of sugar/polyol transport facilitators. Am J Physiol Endocrinol Metab. 2002;282(4):E974-6.http://dx.doi.org/10.1152/ ajpendo.00407.2001. PMid:11882521.

30. Wright EM, Turk E. The sodium/glucose cotransport family SLC5. Pflugers Arch. 2004;447(5):513-5.http://dx.doi.org/10.1007/s00424003-1202-0. PMid:12748858.

31. Machado UF, Schaan BD, Seraphim PM. Glucose transporters in the metabolic syndrome. Arq Bras Endocrinol Metabol. 2006;50(2):17789.http://dx.doi.org/10.1590/S0004-27302006000200004. PMid:16767284.

32. Wu X, Freeze HH. GLUT14, a duplicon of GLUT3, is specifically expressed in testis as alternative splice forms. Genomics. 2002;80(6):553-7.http://dx.doi.org/10.1006/geno.2002.7010. PMid:12504846.

33. Scheepers A, Joost HG, Schürmann A. The glucose transporter families SGLT and GLUT: molecular basis of normal and aberrant function. JPEN J Parenter Enteral Nutr. 2004;28(5):364-71.http:// dx.doi.org/10.1177/0148607104028005364. PMid:15449578.

34. Joost HG, Thorens B. The extended GLUT-family of sugar/polyol transport facilitators: nomenclature, sequence characteristics, and potential function of its novel members (review). Mol Membr Biol. 2001;18(4):247-56.http://dx.doi.org/10.1080/09687680110090456. PMid:11780753.

35. Thorens B, Charron MJ, Lodish HF. Molecular physiology of glucose transporters. Diabetes Care. 1990;13(3):209-18.http:// dx.doi.org/10.2337/diacare.13.3.209. PMid:2407476.

36. Kasanicki MA, Pilch PF. Regulation of glucose-transporter function. Diabetes Care. 1990;13(3):219-27.http://dx.doi.org/10.2337/ diacare.13.3.219. PMid:2407477.

37. Takata K, Kasahara T, Kasahara M, Ezaki O, Hirano H. Erythrocyte/ HepC2-type glucose transporter is concentrated in cells of bloodtissue barriers. Biochem Biophys Res Commun. 1990;173(1):67-73. http://dx.doi.org/10.1016/S0006-291X(05)81022-8. PMid:2256938.

38. Younes M, Brown RW, Stephenson M, Gondo M, Cagle PT. Overexpression of Glut 1 and Glut3 in stage I nonsmall cell lung carcinoma is associated with poor survival. Cancer. 1997;80(6):1046-51. http://dx.doi.org/10.1002/(SICl)1097-0142(19970915)80:6<1046::AIDCNCR6>3.0.CO;2-7 PMid:9305704.

39. Wood IS, Trayhurn P. Glucose transporters (GLUT and SGLT): expanded families of sugar transport proteins. Br J Nutr. 2003;89(1):39.http://dx.doi.org/10.1079/BJN2002763. PMid:12568659.

40. Mo JQ, Dimashkieh HH, Bove KE. GLUT1 endothelial reactivity distinguishes hepatic infantile hemangioma from congenital hepatic vascular malformation with associated capillary proliferation. Hum Pathol. 2004;35(2):200-9.http://dx.doi.org/10.1016/j. humpath.2003.09.017. PMid:14991538.

41. Johann AC, Salla JT, Gomez RS, Aguiar MC, Gontijo B, Mesquita RA. GLUT-1 in oral benign vascular lesions. Oral Dis. 2007;13(1):51-5. http://dx.doi.org/10.1111/j.1601-0825.2006.01246.x. PMid:17241430.

42. Osaki TH, Jakobiec FA, Mendoza PR, Lee Y, Fay AM. Immunohistochemical investigations of orbital infantile hemangiomas and adult encapsulated cavernous venous lesions (malformation versus hemangioma). Ophthal Plast Reconstr Surg. 2013;29(3):183-95. http://dx.doi.org/10.1097/IOP.0b013e31828b0f1f. PMid:23584448.
43. Oliveira DH, Silveira EJ, Medeiros AM, Alves PM, Queiroz LM. Study of the etiopathogenesis and differential diagnosis of oral vascular lesions by immunoexpression of GLUT- 1 and HIF- $1 \alpha$. J Oral Pathol Med. 2014;43(1):76-80.http://dx.doi.org/10.1111/ jop.12092. PMid:23734967.

44. Tasnádi G. Epidemiology and etiology of congenital vascular malformations. Semin Vasc Surg. 1993;6(4):200-3. PMid:8305974.

45. Al-Adnani M, Williams S, Rampling D, Ashworth M, Malone $M$, Sebire NJ. Histopathological reporting of paediatric cutaneous vascular anomalies in relation to proposed multidisciplinary classification system. J Clin Pathol. 2006;59(12):1278-82.http:// dx.doi.org/10.1136/jcp.2006.038240. PMid:16751300.

46. Burrows PE, Laor T, Paltiel H, Robertson RL. Diagnostic imaging in the evaluation of vascular birthmarks. Dermatol Clin. 1998;16(3):455-88. http://dx.doi.org/10.1016/S0733-8635(05)70246-1. PMid:9704205.

47. Freitas TM, Miguel MC, Silveira EJ, Freitas RA, Galvão HC. Assessment of angiogenic markers in oral hemangiomas and pyogenic granulomas. Exp Mol Pathol. 2005;79(1):79-85.http:// dx.doi.org/10.1016/j.yexmp.2005.02.006. PMid:16005715.

48. Leon-Villapalos J, Wolfe K, Kangesu L. GLUT-1: an extra diagnostic tool to differentiate between haemangiomas and vascular malformations. Br J Plast Surg. 2005;58(3):348-52.http://dx.doi. org/10.1016/j.bjps.2004.05.029. PMid:15780229.

49. Seo J, Utumi ER, Zambon CE, et al. Escleroterapia de hemangioma labial. Rev Odonto. 2009;17(34):106-112.

50. Buckmiller LM, Richter GT, Suen JY. Diagnosis and management of hemangiomas and vascular malformations of the head and neck. Oral Dis. 2010;16(5):405-18.http://dx.doi.org/10.1111/j.16010825.2010.01661.x. PMid:20233314.

51. Vasconcelos MG, Alves PM, Vasconcelos RG, Silveira Éj, Medeiros AM, Queiroz LM. Expression of CD34 and CD105 as markers for angiogenesis in oral vascular malformations and pyogenic granulomas. Eur Arch Otorhinolaryngol. 2011;268(8):1213-7. http://dx.doi.org/10.1007/s00405-010-1472-z. PMid:21221622.

52. Berenguer B, Mulliken JB, Enjolras $\mathrm{O}$, et al. Rapidly involuting congenital hemangioma: clinical and histopathologic features. Pediatr Dev Pathol. 2003;6(6):495-510.http://dx.doi.org/10.1007/ s10024-003-2134-6. PMid:15018449.

53. Li Q, Yu Y, Bischoff), Mulliken JB, Olsen BR. Differential expression of CD146 in tissues and endothelial cells derived from infantile haemangioma and normal human skin. J Pathol. 2003;201(2):296302.http://dx.doi.org/10.1002/path.1443. PMid:14517847.

54. Lyons LL, North PE, Mac-Moune Lai F, Stoler MH, Folpe AL, Weiss SW. Kaposiform hemangioendothelioma: a study of 33 cases emphasizing its pathologic, immunophenotypic, and biologic uniqueness from juvenile hemangioma. Am J Surg Pathol. 2004;28(5):559-68.http:// dx.doi.org/10.1097/00000478-200405000-00001. PMid:15105642.

55. Drut RM, Drut R. Extracutaneous infantile haemangioma is also Glut1 positive. J Clin Pathol. 2004;57(11):1197-200.http://dx.doi. org/10.1136/jcp.2003.012682. PMid:15509684.

56. Nguyen VA, Fürhapter C, Romani N, Weber F, Sepp N. Infantile hemangioma is a proliferation of beta 4-negative endothelial cells adjacent to HLA-DR-positive cells with dendritic cell morphology. Hum Pathol. 2004;35(6):739-44.http://dx.doi.org/10.1016/j. humpath.2004.02.005. PMid:15188141.

57. Itinteang T, Tan ST, Jia J, et al. Mast cells in infantile haemangioma possess a primitive myeloid phenotype. J Clin Pathol. 2013;66(7):597 600.http://dx.doi.org/10.1136/jclinpath-2012-201096. PMid:23559352.

58. Dyduch G, Okoń K, Mierzyński W. Benign vascular proliferations-an immunohistochemical and comparative study. Pol J Pathol. 2004;55(2):59-64. PMid:15469208. 
59. Srinivasan B, Ethunandan M, Van der Horst C, Markus AF. Intraosseous 'haemangioma' of the zygoma: more appropriately termed a venous malformation. Int J Oral Maxillofac Surg. 2009;38(10):1066-70. http://dx.doi.org/10.1016/j.ijom.2009.05.010. PMid:19574025.

60. Patiño-Seijas B, Lorenzo-Franco F, Rey-Sanjurjo JL, GonzálezCuesta M, López-Cedrún Cembranos JL. Vascular Lesions: GLUT-1 expression as a diagnostic tool to discriminate tumors from malformations. J Oral Maxillofac Surg. 2012;70(10):2333-42.http:// dx.doi.org/10.1016/j.joms.2011.11.013. PMid:22330334.
Correspondence

Tiago João da Silva Filho

Universidade Federal do Rio Grande do Norte - UFRN Av. Sen. Salgado Filho, 1787 - Lagoa Nova CEP 59056-000, Natal (RN), Brazil Tel.: +55 (84) $32154138 /+55$ (84) 98200469 E-mail: tiagojoaof@gmail.com

Author information

TJSF - PhD candidate at the Graduate Program in Oral Pathology,

Universidade Federal do Rio Grande do Norte (UFRN)

DHIPO - PhD candidate at the Graduate Program in Oral Pathology,

Universidade Federal do Rio Grande do Norte (UFRN)

ISM - Dental student at Universidade Federal do Rio Grande do Norte (UFRN)

LKSM - Dental student at Universidade Federal do Rio Grande do Norte (UFRN)

AKGG - Master's candidate at the Graduate Program in Oral Pathology, Universidade Federal do Rio Grande do Norte (UFRN)

VLMB - PhD candidate at the Graduate Program in Dentistry, Universidade Federal de Pernambuco (UFPE)

LMGQ - Associate professor (level IV) at the School of Dentistry, Universidade Federal do Rio Grande do Norte (UFRN).

Author contributions Conception and design: TJSF Analysis and interpretation: TJSF, ISM, LKSM Data collection: TTJSF, DHIPO, AKGG, VLMB Writing the article: TJSF, VLMB, AKGC Critical revision of the article: AKGG, DHIPO, LMGQ Final approval of the article*: TJSF, DHIPO, ISM, LKSM, AKGG, VLMB, LMGQ

Statistical analysis: TTJSF, DHIPO, AKGG, VLMB Overall responsibility: TJSF

*All authors have read and approved of the final version of the article submitted to J Vasc Bras. 